CARBON MICROSPHEROIDS AS EXTINGUISHING AGENTS FOR METAL FIRES

C. R. Schmitt 


\section{DISCLAIMER}

This report was prepared as an account of work sponsored by an agency of the United States Government. Neither the United States Government nor any agency Thereof, nor any of their employees, makes any warranty, express or implied, or assumes any legal liability or responsibility for the accuracy, completeness, or usefulness of any information, apparatus, product, or process disclosed, or represents that its use would not infringe privately owned rights. Reference herein to any specific commercial product, process, or service by trade name, trademark, manufacturer, or otherwise does not necessarily constitute or imply its endorsement, recommendation, or favoring by the United States Government or any agency thereof. The views and opinions of authors expressed herein do not necessarily state or reflect those of the United States Government or any agency thereof. 


\section{DISCLAIMER}

Portions of this document may be illegible in electronic image products. Images are produced from the best available original document. 


\section{Printed in the United States of America. Available from National Technical Information Service}

U.S. Department of Commerce

5285 Port Royal Road, Springfield, Virginia 22151

Price: Printed Copy \$4.00; Microfiche \$0.95

This report was prepared as an account of work sponsored by the United States Government. Neither the United States nor the United States Atomic Energy Commission, nor any of their employees, nor any of their contractors, subcontractors, or their employees, makes any warranty, express or implied, or assumes any legal liability or responsibility for the accuracy, completeness or usefulness of any information, apparatus, product or process disclosed, or represents that its use would not infringe privately owned rights. 


\title{
CARBON MICROSPHEROIDS AS EXTINGUISHING AGENTS FOR METAL FIRES
}

\author{
C. R. Schmitt
}

Oak Ridge Y-12 Plant

P.O. Box Y, Oak Ridge. Tennessee 37830

Date Issued - August 28, 1973

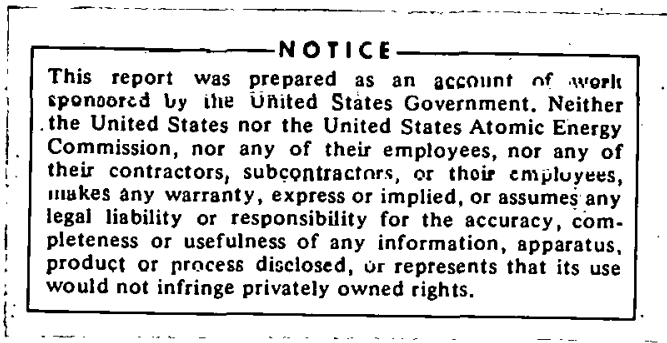

Frepured for the U.S. Atomic Energy Commission Under U.S. Government Contract W.7405eng-26 


\begin{abstract}
Laboratory-prepared and commercially procured carbon microspheroids, having a particle diameter of approximately 100 to 500 micrometers, were characterized analytically and evaluated for their effectiveness as extinguishing agents for metal fires. Their excellent flow and transport properties through a nozzle, high thermal conductivity, chemical inertness, low density, and absence of dusting make them more advantageous than graphite flour or commercial chloride and phosphate powders for extinguishing metal fires.
\end{abstract}




\section{CONTENTS}

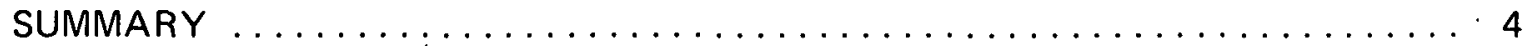

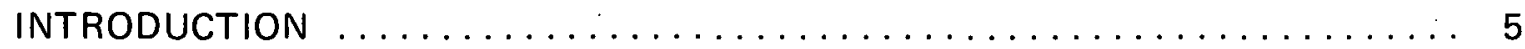

CARBON MICROSPHEROIDS AS FIRE EXTINGUISHANTS $\ldots \ldots \ldots \ldots \ldots \ldots$

Metal Fire-Fighting Feasibility Tests $\ldots \ldots \ldots \ldots \ldots \ldots \ldots \ldots \ldots \ldots \ldots$

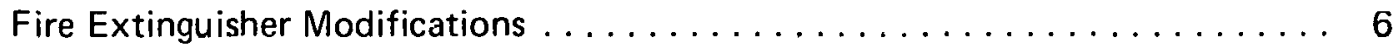

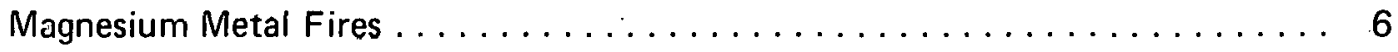

Sodium and Sodium-Potassium Alloy Fire-Fighting Tests $\ldots \ldots \ldots \ldots \ldots \ldots \ldots$

Preparation and Properties of Laboratory-Prepared Carbon Microspheres $\ldots \ldots \ldots \ldots 7$

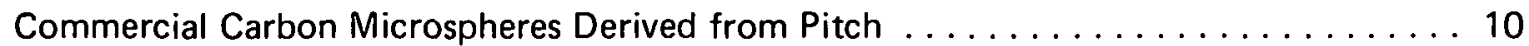

Commercial Carbon Microspheroids Derived from Petroleum Coke . . . . . . . . . 10

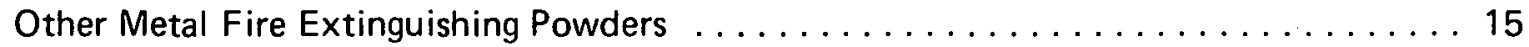

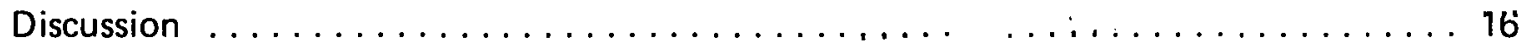

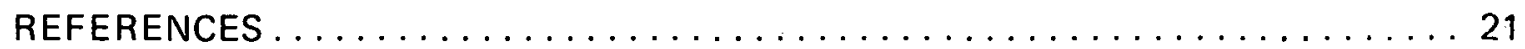

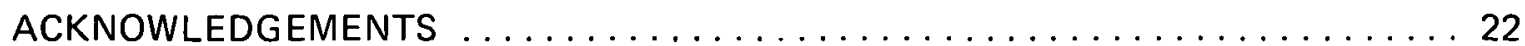




\section{SUMMARY}

Carbon microspheroids, having a particle diameter of 100 to 500 micrometers, as prepared in the laboratory from coked cation resin and as obtained from commercial sources, were evaluated as extinguishing agents for metal fires. Their excellent flow and transport properties through a pressurized, dry-chemical fire extinguisher nozzle, chemical inertness, high thermal conductivity, and absence of dusting make them more advantageous than graphite flour or commercial inorganic chloride and phosphate powders for extinguishing metal fires.

Chemical analyses and physical-property characterization data were also obtained to evaluate the carbon microspheroids with regard to particle size distribution, density, porosity, and sphericity. Although laboratury-prepared carbon microspheres obtained by coking styrene-divinylbenzene cation-exchange reșin microspheres showod the hest sphericity, other carbon microspheroids obtained from commercial sources were also found to be effective fire extinguishing agents. I he carhnn microspheroids had a bulk density in the range of 1.2 to $1.9 \mathrm{gms} / \mathrm{cm}^{3}$, an internal porosity from 0.5 to 10.0 percent, and a major-to-minor axis ratio of up to 1.60 . Some commercial carbon microspheroids obtained from fluidized petroleum coke at a cost of approximately six cents per pound showed particular promise for large-scale metal fire-fighting application because of their relatively low cost. 


\section{INTRODUCTION}

Metals will burn under certain conditions and thus constitute a fire hazard. Some metals oxidize rapidly in the presence of air or moisture and generate sufficient heat to reach their ignition temperature. The alkali metals (sodium, potassium, lithium, and sodium-potassium alloys), for example, are extremely reactive to water, thus water must be carefully avoided in fire-fighting situations involving these metals. Lithium also reacts with nitrogen; however, the other alkali metals are inert to nitrogen.

Those metals that ignite very easily when in the form of finely divided powders, thin sections such as foil or sponge, or in the molten state are referred to as "combustible metals". Included among the combustible metals are: magnesium, titanium, sodium, potassium, lithium, calcium, hafnium, zirconium, zinc, uranium, thorium, and plutonium. Other metals such as aluminum, steel, copper, nickel, tungsten, rhenium, and others, that are not normally thought of as being combustible, may ignite and burn when they are in a finely divided powder form.

Metal fires constitute a serious problem to industry and are most difficult to extinguish because of their intense heat. Such fires are presently extinguished by using special dry-chemical fire extinguishers which contain specially treated inert powders. These extinguishers must be suited to the type of metal involved and are effective only when the amount of metal is small in relation to the amount of extinguishing powder. (1) For some potential metal fire situations, graphite powder is available in pails and metal cans or in sealed, small polyethylene bags for manual application to a fire by shoveling or tossing the material by hand on top of the fire to smother it. All of these methods, however, are generally unsatisfactory because either the inert powders sometime become plugged in the extinguisher hose nozzles, the powders are highly corrosive to nearby capital equipment items, or a large cloud of graphite dust is created in the nearby vicinity, thus generating a secondary explosion hazard.

Some of the general requirements ${ }^{(2)}$ for a dry-chemical powder suitable for use in a pressurized dry-chemical fire extinguisher are: (1) must be free flowing, (2) have a particular grain size, (3) be able to pass through specifically designed nozzles, (4) can be discharged at a designed rate, (5) will cover the fire in a prescribed pattern, and (6) be applicable over a specific range.

In addition, the powder should be nonreactive to all combustible metals when hot and be nonhygroscopic so that caking and nozzle-plugging difficulties do not arise.

The primary objective of this study was to dernonstrate the feasibility of using carbon microspheres and microspheroids for extinguishing metal fires when applied by pressurizing through a modifien dry-chemical fire extinguisher and nozzle. Physical-property characterization data were also needed to relate such properties as particle-size distribution, density, porosity, and sphericity with regard to its fire-fighting effectiveness. 


\section{CARBON MICROSPHEROIDS AS FIRE EXTINGUISHANTS}

\section{METAL FIRE-FIGHTING FEASIBILITY TESTS}

\section{Fire Extinguisher Modifications}

A commercial dry-chemical fire extinguisher was modified for feasibility metal fire extinguishing tests using carbon microspheres by installing a 3/4-inch gate valve between the carbon dioxide pressurizing cartridge and the extinguisher chamber as a safety precaution in the event that plugging of the hose nozzle occurred. A diagrammatic representation of the dry-chemical fire extinguisher, as modified, is given in Figure 1.

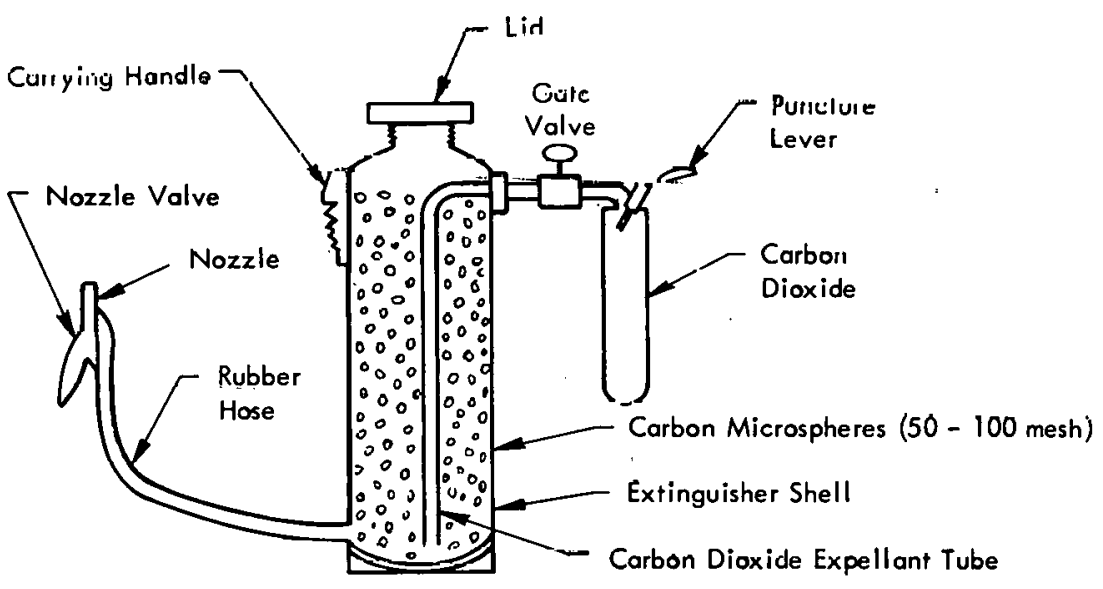

Figure 1. MODIFIED DRY-CHEMICAL FIRE EXTINGUISHER USED WITH CARB̃ON MICROSPHERES.

\section{Magnesium Metal Fires}

A pile of magnesium metal chips $(\sim 1 / 2 \mathrm{lb})$ was ignited by means of burning oil while contained within a rectangular stainless steel pan ( $\sim 4$ "deep $\times 12^{\prime \prime}$ wide $\times 24^{\prime \prime}$ long). After the magnesium chips had attained a white-heat intensity, a stream of the carbon microspheres was directed onto the fire, using the modified dry-chemical fire extinguisher previously described, from a distance of 20 to 25 feet. The carbon microspheres were directed onto the pan of burning magnesium with a very high degree of accuracy and readily extinguished the fire in less than a minute by smothering it and by conducting the heat away.

In a second test, carbon microspheres sealed with a polyethylene bag were placed on an iron ring stand above a pan of burning magnesium metal. The heat from the fire quickly melted a large hole in the polyethylene bag and allowed the carbon microspheres to drop into the stainless steel pan containing the burning magnesium chips. The blaze was extinguished automatically in about one second. This method simulated an automatic and effective way to extinguish a 'metal fire within glove-box enclosures. Carbon or graphite microspheres could be contained within a blanket or bag of thermoplastic material such as polyethylene and could be suspended at the ceiling of a glove-box enclosure such that the microspheres 
would automatically flow downward by gravity to extinguish a metal fire if one occurred even if the glove box was unattended.

\section{SODIUM AND SODIUM-POTASSIUM ALLOY FIRE-FIGHTING TESTS}

Recent metal fire extinguishing tests on sodium and sodium-potassium alloy were made by a member of the Y-12 Fire Protection Engineering Department to compare the effectiveness of various dry-chemical powders for controlling and extinguishing metal fires. Four cartridge-pressurized dry-chemical fire extinguishers were loaded with standard graphite flour, a commercially procured sodium chloride powder, a commercially procured ammonium phosphate powder, and three varieties of carbon microspheroids (carbon microspheres prepared by coking a cation-exchange resin, carbon microspheres obtained commercially from a pitch precursor, and commercially procured petroleum coke microspheroids).

Although all of these agents were ultimately effective in quenching and extinguishing the fires after a sufficient layer of these materials had formed over the burning metal surfaces, the carbon microspheres suppressed the fires in the shortest time and required significantly less material since very little was lost to atmospheric dusting.

\section{PREPARATION AND PROPERTIES OF LABORATORY-PREPARED CARBON MICRO- SPHERES}

For the preliminary magnesium metal fire-fighting tests described previously, a 50-pound batch of the carbon microspheres was prepared by coking some commercially available cation-exchange resin spheres at $900^{\circ} \mathrm{C}$ in a flowing nitrogen atmosphere. The cation resin consisted of a copolymer of styrene and divinylbenzene having a twelve percent crosslinkage. The resin spheres were first oven dried at $100^{\circ} \mathrm{C}$ to remove their residual moisture content and were then transferred to a large rectangular graphite tray and spread out to a relatively shallow bed depth of approximately two inches and coked in a furnace at $900^{\circ} \mathrm{C}$ in a flowing nitrogen atmosphere using a programmed temperature heating cycle over a period of 48 hours to attain the $900^{\circ} \mathrm{C}$ temperature.

A photomicrograph showing the general size range and sphericity of these carbon microspheres is presented in Figure 2. Fifty coked resin microspheres were then chosen at random to evaluate their degree of sphericity. The diameter of each carbon microsphere was measured in two directions with the second measurement taken 90 degrees from the first measurement. Carbon microsphere sphericity data are summarized in Table 1. Analytical and pore-size distribution data on the carbon microspheres are given in Table 2 and Figure 3.

Compressive strength of the individual carbon microsphere particles prepared by coking cation-resin microspheres containing 16 percent divinylbenzene as a crosslinking agent is summarized in Table 3.

Various types of carbon microsphere precursor materials were coked at $900^{\circ} \mathrm{C}$ in a flowing nitrogen atmosphere to determine their carbon yield and retention of sphericity after coking. A batch of commercially available nonactivated styrene-divinylbenzene r.opolymer spheres (18 - 50 mesh) gave a 13.2 percent carbon yield, but the carbon material formed had 


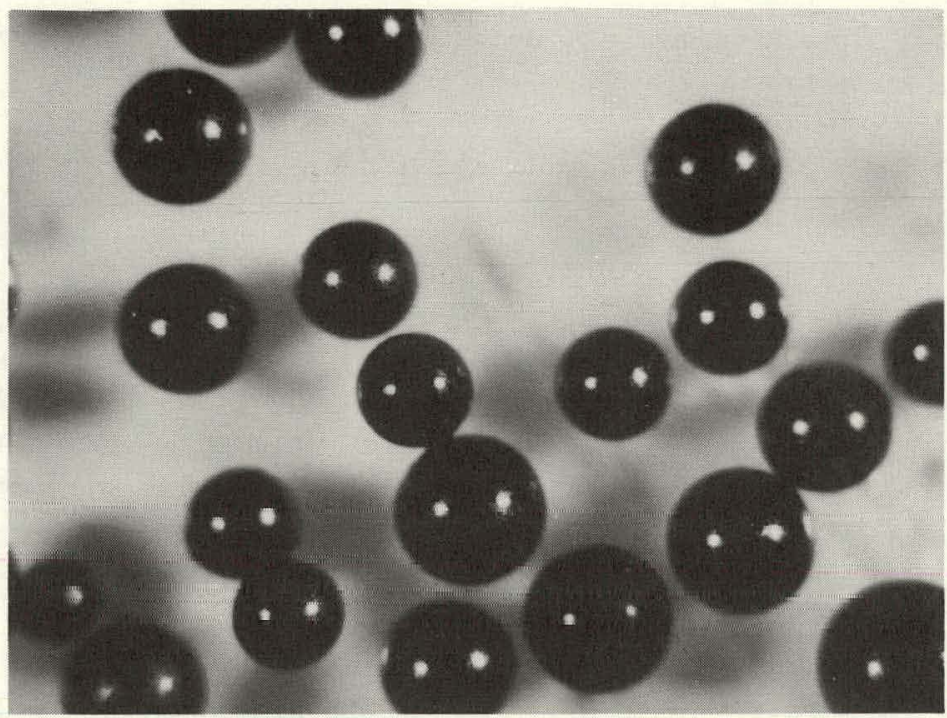

(a) Top View. (40X)

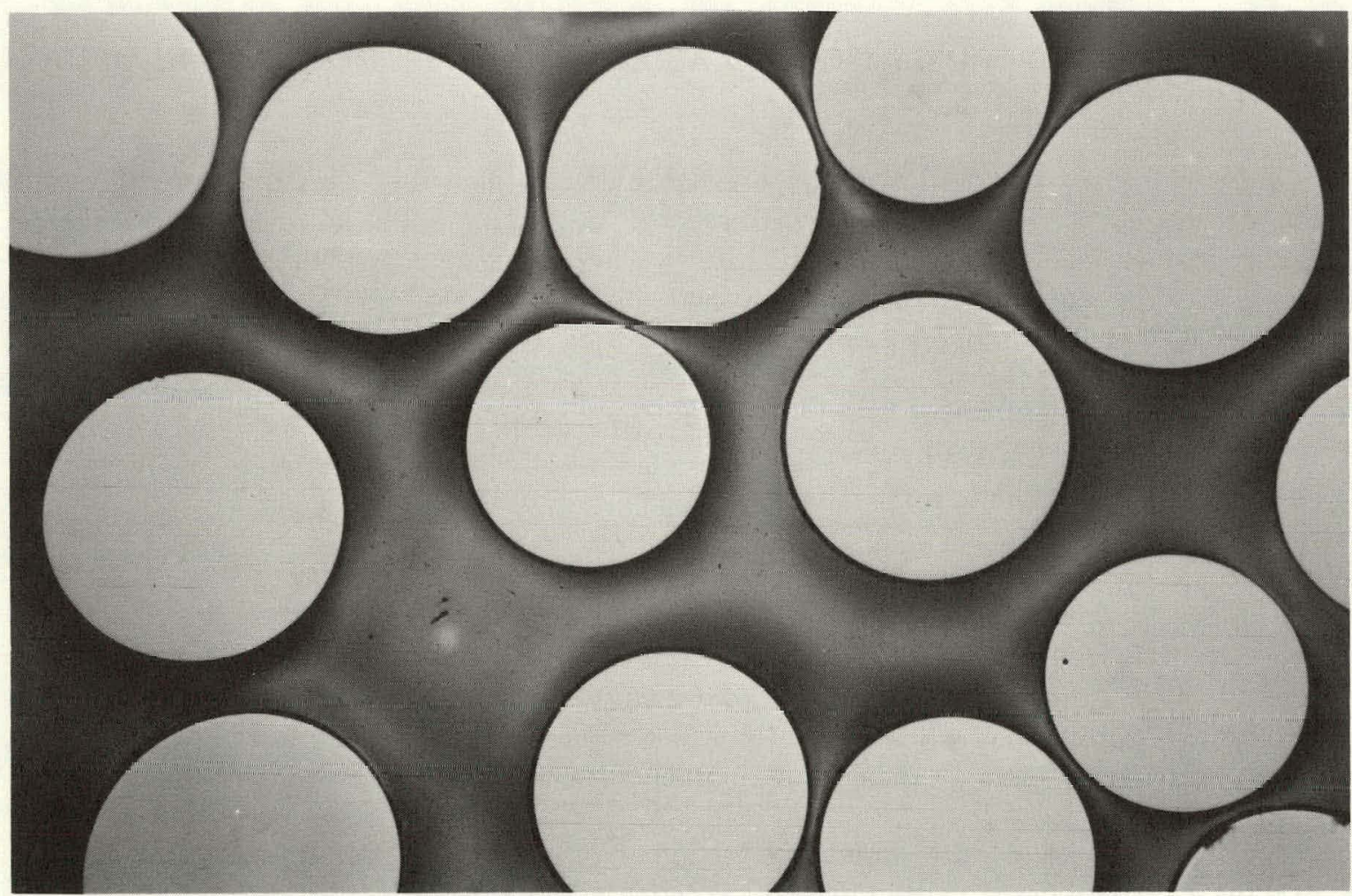

(b) Cross-Sectional View. (100X)

Figure 2. PHOTOMICROGRAPHS OF CARBON MICROSPHERES PREPARED FROM COKED CATION RESIN. 
Table 1

SPHERICITY OF CARBON MICROSPHERES PREPARED BY COKING CATION-RESIN MICROSPHERES AT $900^{\circ} \mathrm{C}$

\begin{tabular}{|c|c|c|c|c|}
\hline \multirow{2}{*}{$\begin{array}{l}\text { Sphere } \\
\text { Number }\end{array}$} & \multicolumn{2}{|c|}{ Diameter $(\mu \mathrm{m})$} & \multirow[b]{2}{*}{ Diameter Ratio (1) } & \multirow{2}{*}{$\begin{array}{c}\text { Percent Variation } \\
\text { from a Perfect } \\
\text { Sphere }\end{array}$} \\
\hline & At $0^{\circ} \mathrm{C}$ & At $90^{\circ} \mathrm{C}$ & & \\
\hline 1 & 210 & 213 & 1.01 & 1 \\
\hline 2 & 249 & 247 & 0.99 & -1 \\
\hline 3 & 317 & 326 & 1.03 & 3 \\
\hline 4 & 311 & 312 & 1.00 & 0 \\
\hline 5 & 286 & 286 & 1.00 & 0 \\
\hline 6 & 326 & 325 & 1.00 & 0 \\
\hline 7 & 301 & 301 & 1.00 & 0 \\
\hline 8 & 251 & 246 & 0.98 & -2 \\
\hline 9 & 320 & 317 & 0.99 & -1 \\
\hline 10 & 256 & 258 & 1.01 & 1 \\
\hline 11 & 266 & 262 & 0.98 & -2 \\
\hline 12 & 248 & 246 & 0.99 & -1 \\
\hline 13 & 315 & 311 & 1.00 & U \\
\hline 14 & 354 & 353 & 1.00 & 0 \\
\hline 15 & 237 & 234 & 0.99 & -1 \\
\hline 16 & 296 & 294 & 0.99 & -1 \\
\hline 17 & 205 & 203 & 0.99 & -1 \\
\hline 18 & 218 & 218 & 1.00 & 0 \\
\hline 19 & 218 & 218 & 1.00 & 0 \\
\hline 20 & 255 & 249 & 0.98 & -2 \\
\hline 21 & 293 & 290 & 0.99 & -1 \\
\hline 22 & 240 & 238 & 0.99 & -1 \\
\hline 23 & 426 & 422 & 0.99 & -1 \\
\hline 24 & 414 & 410 & 0.99 & -1 \\
\hline 25 & 318 & 316 & 0.99 & -1 \\
\hline 26 & 563 & 565 & 1.00 & 0 \\
\hline 27 & 296 & 297 & 1.00 & 0 \\
\hline 28 & 272 & 271 & 1.00 & 0 \\
\hline 29 & 353 & 356 & 1.01 & 1 \\
\hline 30 & 269 & 271 & 1.01 & 1 \\
\hline 31 & 266 & 266 & 1.00 & 0 \\
\hline 32 & 318 & 320 & 1.01 & 1 \\
\hline 33 & 264 & 265 & 1.00 & 0 \\
\hline 34 & 147 & 146 & 1.00 & 0 \\
\hline 35 & 336 & 336 & 1.00 & 0 \\
\hline 36 & 388 & 388 & 1.00 & 0 \\
\hline 37 & 222 & 223 & 1.00 & 0 \\
\hline 38 & 301 & 302 & 1.00 & 0 \\
\hline 39 & 232 & 233 & 1.00 & 0 \\
\hline 40 & 256 & 255 & 1.00 & 0 \\
\hline 41 & 344 & 350 & 1.02 & 2 \\
\hline 42 & 185 & 187 & 1.01 & 1 \\
\hline 43 & 189 & 191 & 1.01 & 1 \\
\hline 44 & 336 & 339 & 1.01 & 1 \\
\hline 45 & 360 & 371 & 1.03 & 3 \\
\hline 46 & 555 & 546 & 0.98 & -2 \\
\hline 47 & 209 & 210 & 1.00 & 0 \\
\hline 48 & 207 & 207 & 1.00 & 0 \\
\hline 49 & 223 & 225 & 1.01 & 1 \\
\hline 50 & 278 & 277 & 1.00 & 0 \\
\hline
\end{tabular}

(1) Diameter at $90^{\circ} \mathrm{C} /$ diameter at $0^{\circ} \mathrm{C}$. 
foamed appreciably during coking and was unsatisfactory. A batch of commercially available polyacrylic resin spheres gave a 23.0 percent carbon yield, but the carbon material formed was badly fused together and was also unsatisfactory.

\section{COMMERCIAL CARBON MICRO- SPHERES DERIVED FROM PITCH}

Samples of commercial carbon microspheres prepared from a high-purity pitch were obtained from a commercial source and evaluated for particle-size distribution, sphericity, porosity, and other characterization tests. The sphericity uf these pitch-derived carbon microspheres is reported in Table 4 and Figure 4. Analytical and pore-size distribution data are given in Table 5 and Figure 5 , and particle-size distribution analyses are presented in Figure 6.

Table 3

COMPRESSIVE STRENGTH OF CARBON MICROSPHERES PREPARED FROM CATION RESIN SPHERES (16\% Crosslinkage)

\begin{tabular}{rcc}
\hline Sample & $\begin{array}{c}\text { Diameter } \\
\text { (Inils) }\end{array}$ & $\begin{array}{c}\text { Compressive } \\
\text { Fracture Load } \\
\text { (ounces) }\end{array}$ \\
\hline 1 & 5.0 & 45 \\
2 & 5.4 & 57 \\
3 & 5.9 & 24 \\
4 & 6.7 & 52 \\
5 & 6.2 & 17 \\
6 & 6.0 & 41 \\
7 & 5.6 & 60 \\
8 & 5.5 & 35 \\
9 & 5.9 & 52 \\
10 & 5.8 & 52 \\
11 & 4.9 & 29 \\
12 & 6.4 & 52 \\
\hline Average & 5.8 & 43.6 \\
\hline
\end{tabular}
ant for metal fires. The low cost of this material (approximately six cents a pound) would make it highly attractive for large-scale industrial usage for metal fire fighting.

Photomicrographs of some of the fluidized petroleum coke microspheroids are given in
Figures 7 and 8 . Although some of these particles are quite angular and nonspherical in
shape, such irregular particles could be readily removed by dry sieving or vibratory table

Photomicrographs of some of the fluidized petroleum coke microspheroids are given in
Figures 7 and 8 . Although some of these particles are quite angular and nonspherical in
shape, such irregular particles could be readily removed by dry sieving or vibratory table

Photomicrographs of some of the fluidized petroleum coke microspheroids are given in
Figures 7 and 8 . Although some of these particles are quite angular and nonspherical in
shape, such irregular particles could be readily removed by dry sieving or vibratory table upgrading techniques if increased nozzle flowability properties were required.

ANALYTICAL DATA ON CARBON MICROSPHERES PREPARED FROM COKED CATION RESIN

\begin{tabular}{lc}
\hline Carbon (\%) & 95.1 \\
Oxygen (\%) & 0.90 \\
Hydrogen (\%) & 0.3 \\
Bulk Density (gms $/ \mathrm{cm}^{3}$ ) & 1.438 \\
Real Density $\left(\mathrm{gms} / \mathrm{cm}^{3}\right.$ ) & 1.446 \\
Surface Area $\left(\mathrm{cm}^{2} / \mathrm{gm}\right)$ & 0.035 \\
Pornsity $(\%)$ & 0.52 \\
Porosity $<10$ Micrometers $(\%)$ & 94.77 \\
Volume-Average Equivalent Pore & 2.90 \\
Viameter ( $\mu \mathrm{min})$ &
\end{tabular}

Spark-source mass spectrographic analyses were obtained on the commercial carbon microspheres derived from pitch to determine their chemical purity. Results, as summarized in Table 6, show that the principal elemental impurities were sulfur, magnesium, aluminum, iron, and silicon. The total elemental impurities delected was only $2,670 \mathrm{ppm}$ when counting "less thans" at full value.

\section{COMMERCIAL CARBON MICRO- SPHEROIDS DERIVED FROM PETROL- EUM COKE}

Laboratory evaluation tests on commercially procured fluidized petroleum coke micruspheroids showed that this material exhibited excellent flowability and was highly suitable as an extinguish-
(approximately six cents a pound) would 


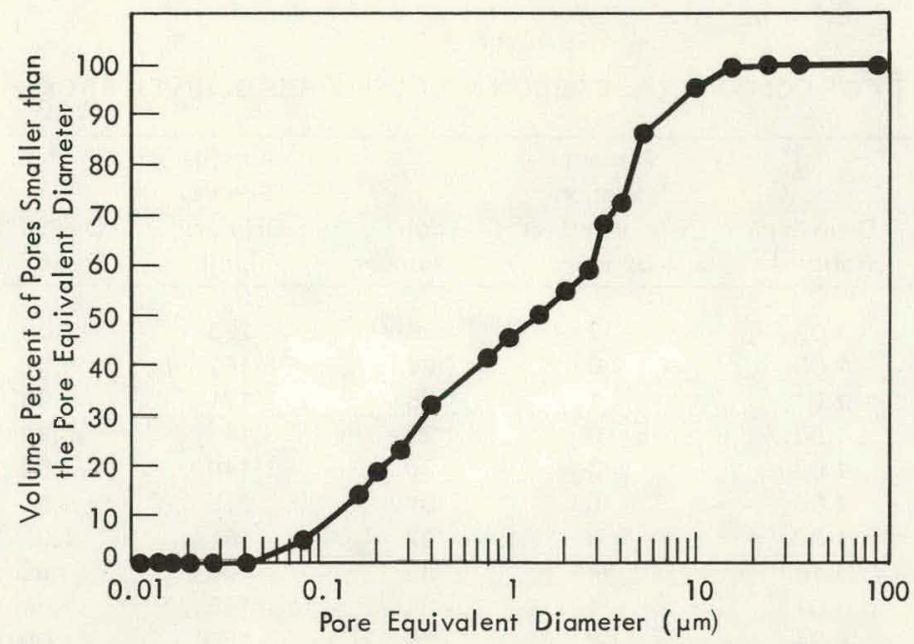

Figure 3. PORE-SIZE DISTRIBUTION OF CARBON MICROSPHERES PREPARED FROM COKED CATION RESIN.

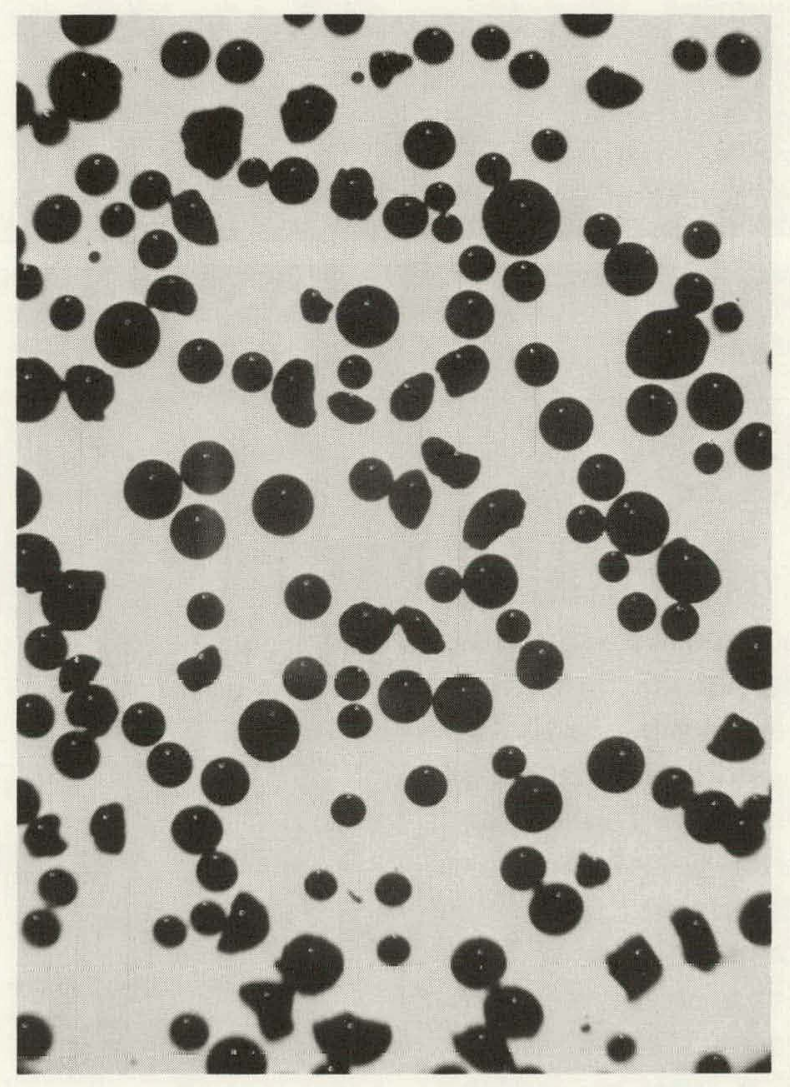

Figure 4. PHOTOMICROGRAPH OF COMMERCIAL CARBON MICROSPHERES DERIVED FROM PITCH. (40X) 
Table 4

SPHERICITY OF COMMERCIAL CARBON MICROSPHERES DERIVED FROM PITCH

\begin{tabular}{|c|c|c|c|c|c|c|c|}
\hline $\begin{array}{l}\text { Sphere } \\
\text { Number }\end{array}$ & $\begin{array}{c}\text { Average } \\
\text { Sphere } \\
\text { Diameter } \\
(\mu \mathrm{m})\end{array}$ & $\begin{array}{l}\text { Diameter } \\
\text { Ratio (1) }^{-}\end{array}$ & $\begin{array}{c}\text { Percent } \\
\text { Variation } \\
\text { from a Perfect } \\
\text { Sphere }\end{array}$ & $\begin{array}{l}\text { Sphere } \\
\text { Number }\end{array}$ & $\begin{array}{c}\text { Average } \\
\text { Sphere } \\
\text { Diameter } \\
(\mu \mathrm{m})\end{array}$ & $\begin{array}{l}\text { Diameter } \\
\text { Ratio(1) }\end{array}$ & $\begin{array}{c}\text { Percent } \\
\text { Variation } \\
\text { from a Perfect } \\
\text { Sphere }\end{array}$ \\
\hline 1 & 249 & 1.02 & 2 & $26^{(2)}$ & 265 & 1.00 & 0 \\
\hline 2 & 217 & 1.00 & 0 & 27 & 162 & 1.01 & 1 \\
\hline 3 & 212 & 1.01 & 1 & 28 & 171 & 0.99 & -1 \\
\hline 4 & 243 & 1.00 & 0 & 29 & 147 & 0.99 & -1 \\
\hline 5 & 192 & 1.03 & 3 & 30 & 140 & 1.09 & 9 \\
\hline $6^{\circ}$ & 171 & 1.00 & 0 & 31 & 215 & 1.01 & 1 \\
\hline 7 & 153 & 1.03 & 3 & 32 & 161 & 1.00 & 0 \\
\hline 8 & 204 & 114 & 14 & 33 & 206 & 0.99 & -1 \\
\hline 0 & 182 & 1.01 & 1 & .34 & 155 & 1.00 & 0 \\
\hline 10 & 227 & 0.91 & -9 & 35 & 150 & 1.00 & 0 \\
\hline 11 & 190 & 0.90 & -10 & 36 & 165 & 1.00 & 0 \\
\hline 12 & 127 & 1.02 & 2 & 31 & 237 & 0.99 & -1 \\
\hline 13 & 151 & 1.01 & 1 & 38 & 232 & 1.01 & 1 \\
\hline 14 & 191 & 1.01 & 1 & 39 & 176 & 1.00 & 0 \\
\hline 15 & 158 & 1.01 & 1 & $40^{(3)}$ & 133 & 1.01 & 1 \\
\hline 16 & 182 & 0.99 & -1 & 41 & 183 & 0.99 & -1 \\
\hline 17 & 241 & 1.00 & 0 & 42 & 137 & 1.00 & 0 \\
\hline 18 & 183 & 1.00 & 0 & 13 & 205 & $1 \mathrm{n} 1$ & 1 \\
\hline 19 & 199 & 0.99 & -1 & 44 & 221 & 1.07 & 7 \\
\hline 20 & 240 & 1.02 & 2 & 45 & 244 & 0.99 & -1 \\
\hline 21 & 231 & 1.00 & 0 & 46 & 203 & 0.94 & -6 \\
\hline 22 & 207 & 1.02 & 2 & 47 & 218 & 0.99 & -1 \\
\hline 23 & 185 & 1.00 & 0 & 48 & 213 & 0.94 & -6 \\
\hline 24 & 212 & 0.96 & -4 & 49 & 181 & 1.00 & 0 \\
\hline 25 & 211 & 0.99 & -1 & 50 & 203 & 1.00 & 0 \\
\hline
\end{tabular}

(1) Diameter at $90^{\circ} \mathrm{C} /$ diameter at $0^{\circ} \mathrm{C}$.

(2) Largest diameter sphere in batch.

(3) Smallest diameter sphere in batch.

It is also shown in Figure 8 that the internal structure associated with the fluid petroleum coke microspheroids consists of concentric carbon layers sımılar to that of an onion. Analytical and pore-size distribution data are presented in Table 7 and Figure 9. The fluidized petroleum coke microspheroids were determined to have an average major-to-minor axis ratio of 1.25. Sphericity data obtained on these microspheroids are summarized in Table 8. Particle-size distribution analyses of the petroleum coke microspheroids are noted in the graph of Figure 10.
Table 5

ANALYTICAL AND PORE-SIZE DISTRIBUTION DATA FOR COMMERCIAL CARBON MICROSPHERES DERIVED FROM PITCH

\begin{tabular}{lc}
\hline Bulk Density $\left(\mathrm{gms}_{\mathrm{s}} / \mathrm{cm}^{3}\right)$ & 1.349 \\
Porosity $(\%)$ & 9.25 \\
Real Density $\left(\mathrm{gms} / \mathrm{cm}^{3}\right)$ & 1.487 \\
Porosity Less Than 10 Micrometers (\%) & 96.10 \\
Surface Area $\left(\mathrm{m}^{2} / \mathrm{gm}\right)$ & 7.068 \\
Volume-Average Equivalent Pore & 1.48 \\
Diameter $(\mu \mathrm{m})$ & \\
\hline
\end{tabular}




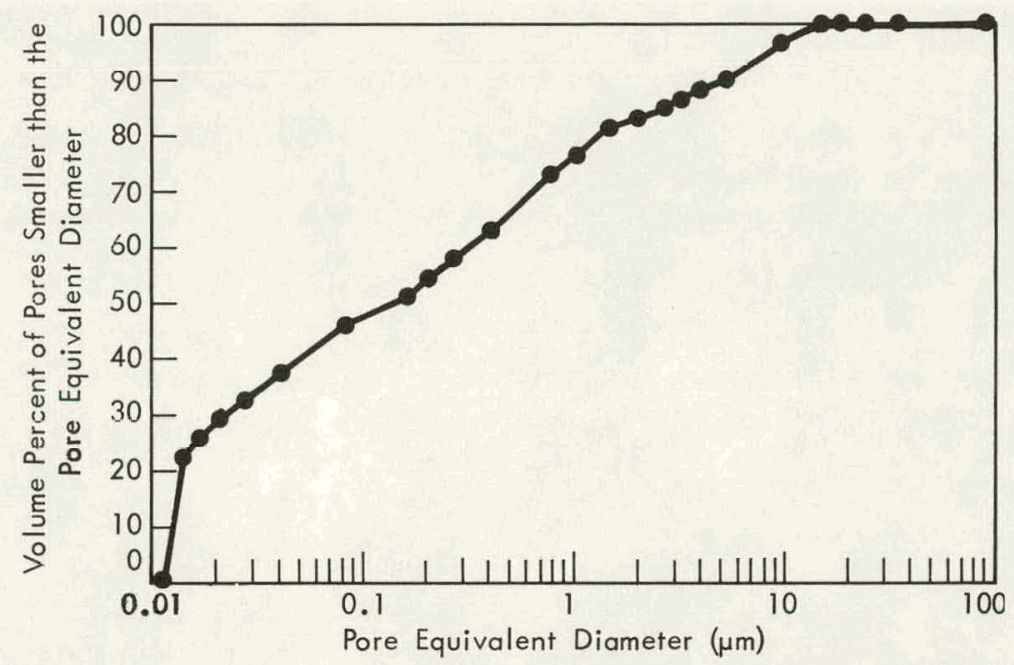

Figure 5. PORE-SIZE DISTRIBUTION OF COMMERCIAL CARBON MICROSPHERES DERIVED FROM PITCH.

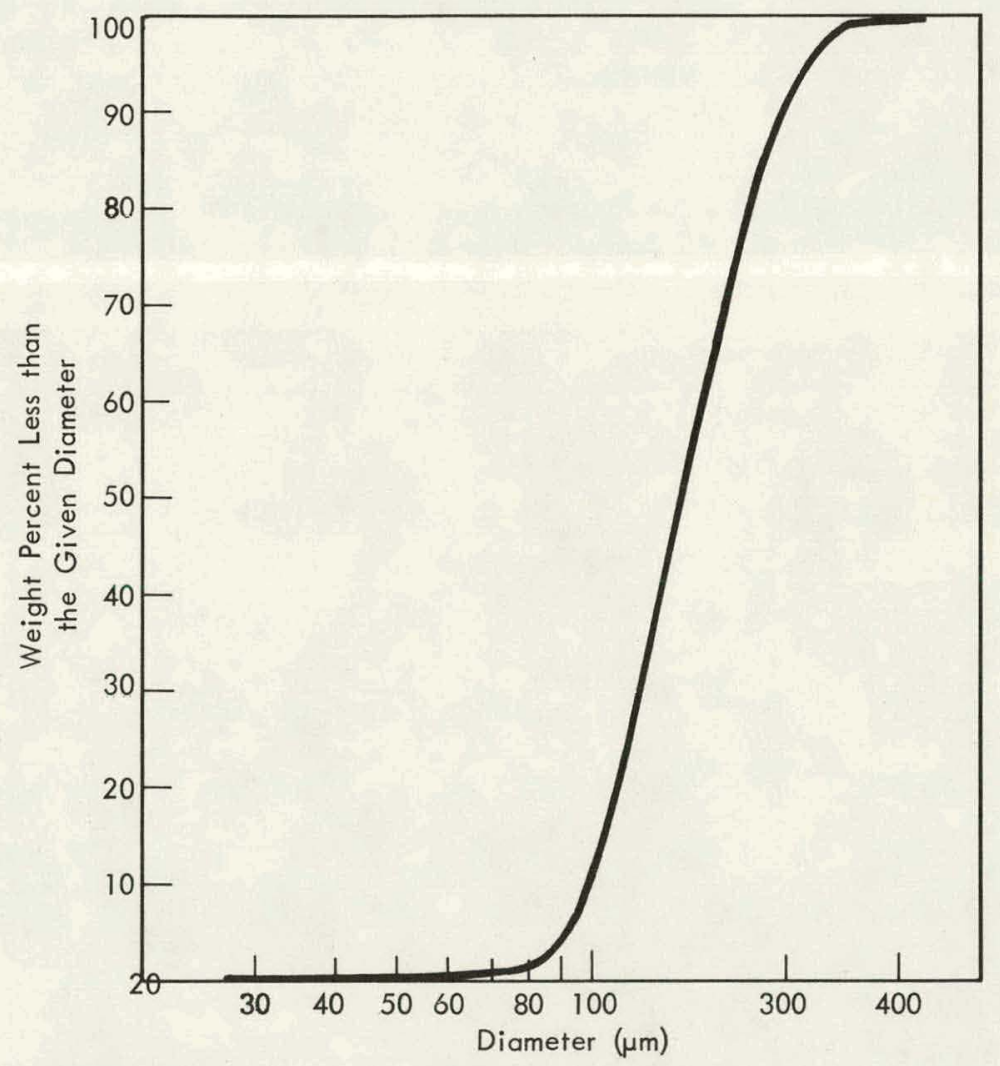

Figure 6. PARTICLE-SIZE DISTRIBUTION OF COMMERCIAL CARBON MICROSPHERES DERIVED FROM PITCH. 


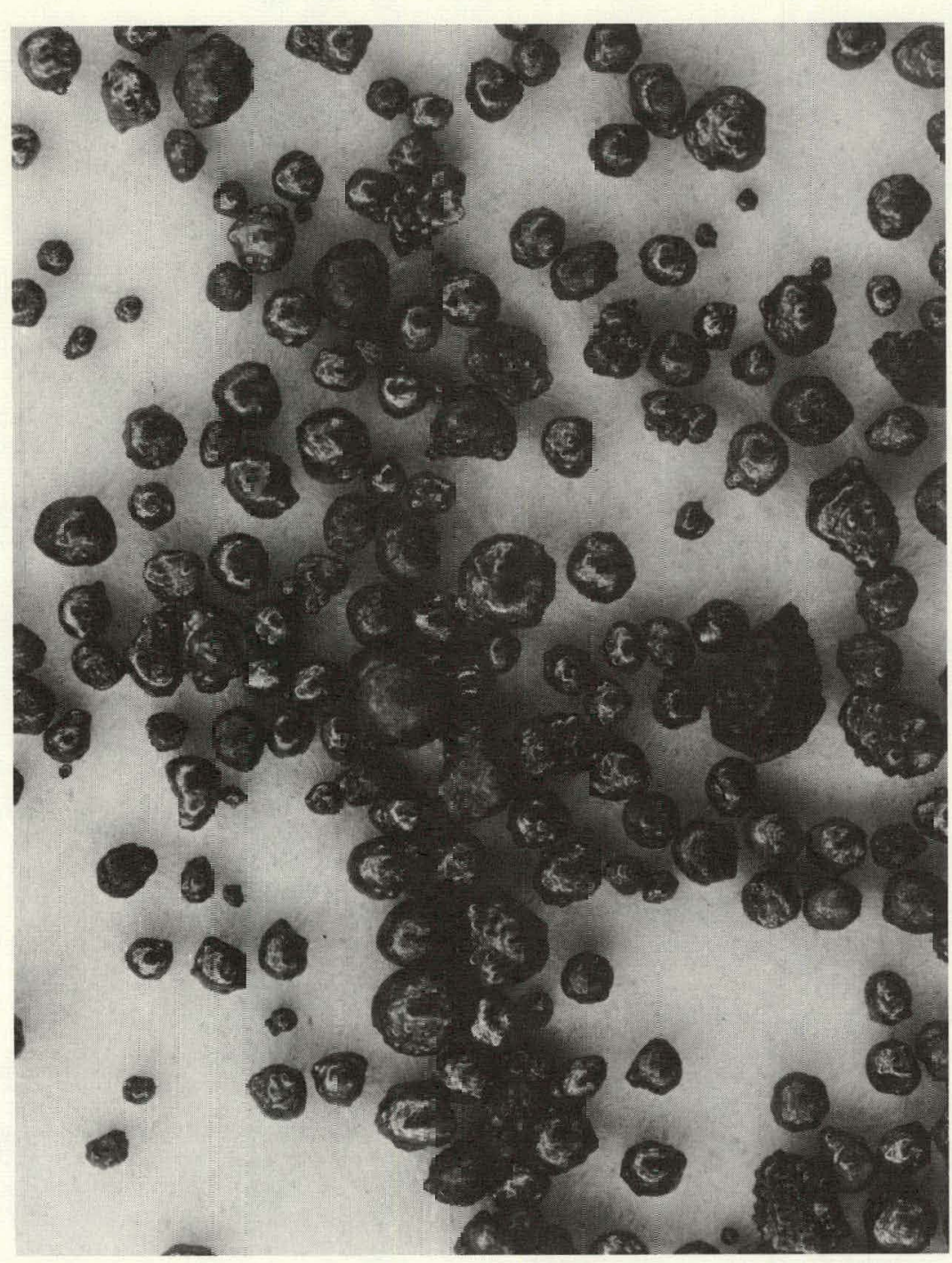

JミA

Figure 7. PHOTOMIROGF.APH OF FLUIDIZED PETROLEUM COKE MICRO SPHEROIDS SHOW NG GEIJERAL SPHERICITY. (15X)

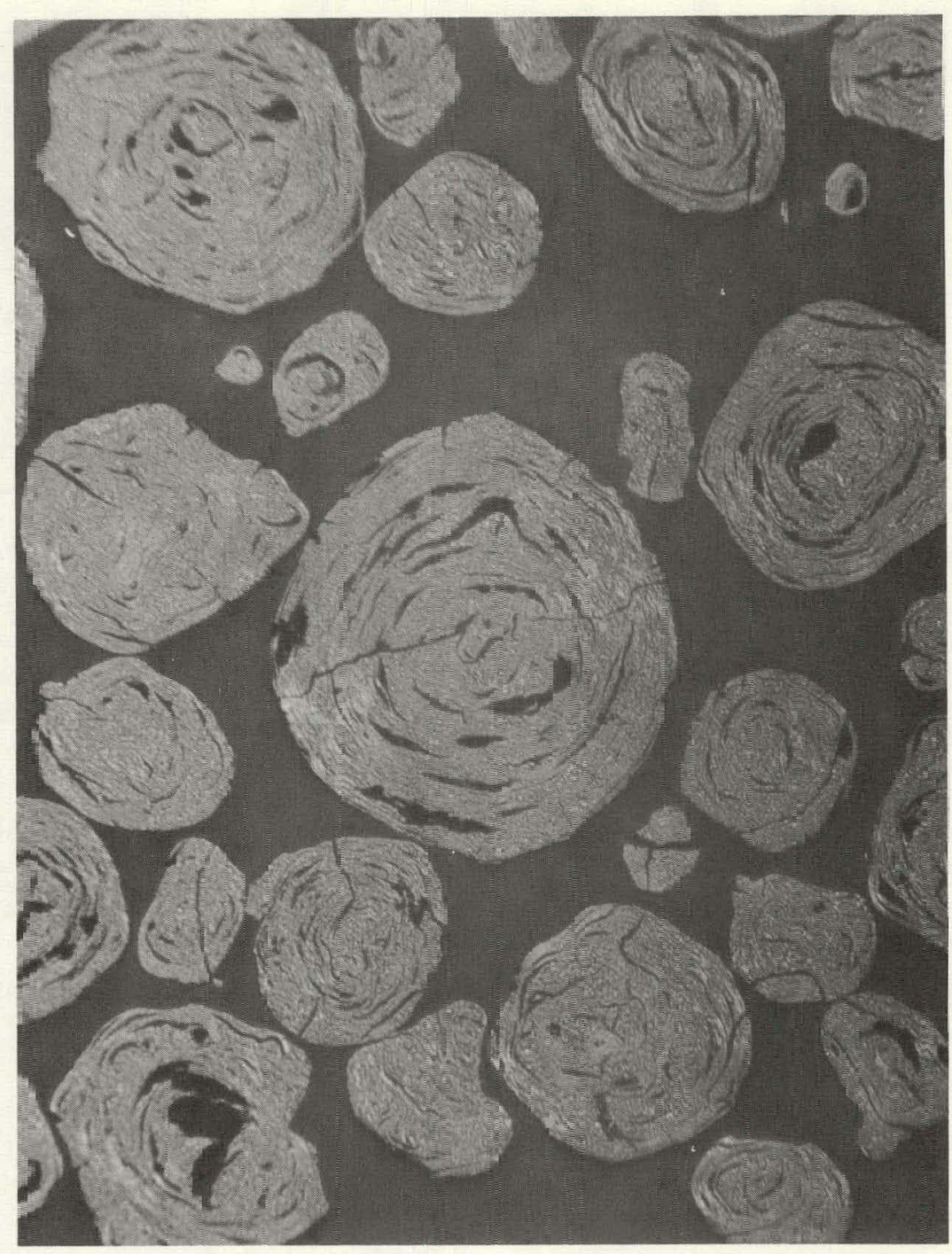

Figure 8. PHOTOMICROGFAPH OF FLUIDIZED PETRCLEUM COKE MICROSPHEROIDS SHOWING INTERNAL POROSITY. (Cross-Sectional View; Sensitive Tint; 100X) 
Table 6

SPARK-SOURCE MASS SPECTROGRAPHIC ANALYSES

OF COMMERCIAL CARBON MICROSPHERES

DERIVED FROM PITCH

\begin{tabular}{|c|c|c|c|}
\hline Element & $\begin{array}{c}\text { Concentration } \\
\text { (wppm) }\end{array}$ & Element & $\begin{array}{c}\text { Concentration } \\
\text { (wppm) }\end{array}$ \\
\hline $\mathrm{Ag}$ & Matrix $\{1\}$ & Mo & $<2.0$ \\
\hline Al & 450.0 & $\mathrm{Na}$ & 20.0 \\
\hline As & 4.0 & $\mathrm{Nb}$ & $<0.5$ \\
\hline $\mathrm{Au}$ & 3.0 & $\mathrm{Nd}$ & $<3.0$ \\
\hline B & 0.7 & $\mathrm{Ni}$ & 7.0 \\
\hline $\mathrm{Ba}$ & $<1.0$ & Os & $<3.0$ \\
\hline $\mathrm{Be}$ & 0.07 & $\mathbf{P}$ & 40.0 \\
\hline $\mathrm{Bi}$ & $<1.0$ & $\mathrm{~Pb}$ & $<2.0$ \\
\hline $\mathrm{Br}$ & $<0.9$ & Pd & $<2.0$ \\
\hline $\mathrm{Ca}$ & 200.0 & $\mathrm{Pr}$ & $<0.8$ \\
\hline $\mathrm{Cd}$ & $<2.0$ & $P_{t}$ & $<3.0$ \\
\hline $\mathrm{Ce}$ & $<0.9$ & $\mathrm{Rb}$ & 2.0 \\
\hline $\mathrm{Cl}$ & 80.0 & $\operatorname{Re}$ & $<2.0$ \\
\hline Co & 5.0 & $R h$ & $<0.6$ \\
\hline $\mathrm{Cr}$ & 5.0 & Ru & $<2.0$ \\
\hline Cs & 2.0 & $\mathrm{~s}$ & 500.0 \\
\hline $\mathrm{Cu}$ & 2.0 & $\mathrm{Sb}$ & 3.0 \\
\hline DV & $<3.0$ & Sc & 0.7 \\
\hline Er & $<3.0$ & Se & $<0.9$ \\
\hline $\mathrm{Eu}$ & $<\mathbf{2 . 0}$ & $\mathrm{Si}$ & 300.0 \\
\hline$F$ & 3.0 & Sm & $<3.0$ \\
\hline $\mathrm{Fe}$ & 350.0 & $\mathrm{Sn}$ & 20.0 \\
\hline $\mathrm{Ga}$ & $<0.6$ & $\mathrm{Sr}$ & $<0.6$ \\
\hline Gd & $<4.0$ & $\mathrm{Ta}$ & $<30.0$ \\
\hline $\mathrm{Ge}$ & $<1.0$ & $\mathrm{~Tb}$ & $<0.9$ \\
\hline $\mathrm{Hf}$ & $<4.0$ & $\mathrm{Te}$ & $<2.0$ \\
\hline $\mathrm{Hg}$ & $<4.0$ & Th & $<1.0$ \\
\hline Ho & $<0.9$ & $\mathrm{Ti}$ & 40.0 \\
\hline 1 & $<0.7$ & $\mathrm{TI}$ & $<2.0$ \\
\hline In & $<0.6$ & $\mathrm{Tm}$ & $<0.9$ \\
\hline Ir & $<2.0$ & $u$ & $<1.0$ \\
\hline$K$ & 10.0 & v & 4.0 \\
\hline La & $<0.8$ & $w$ & $<3.0$ \\
\hline Lu & $<1.0$ & $Y$ & $<0.5$ \\
\hline $\mathrm{Mg}$ & 500.0 & $\mathrm{Yb}$ & $<3.0$ \\
\hline \multirow[t]{2}{*}{$\mathrm{Mn}$} & 3.0 & $\mathrm{Zn}$ & 2.0 \\
\hline & & $\mathrm{Zr}$ & 10.0 \\
\hline
\end{tabular}

(1) Silver used as a carrier for analysis.

\section{OTHER METAL FIRE EXTINGUISHING POWDERS}

Various analytical characterization data were obtained on three of the conventional metal fire extinguishing powders. Particle-size distribution analyses of these powders are compared in Table 9 and presented as graphs in Figures 11 through 13.

As noted in Table 9, the average particle diameter of the graphite flour (99.8\% carbon) and commercial ammonium phosphate powders is considerably smaller than that of the laboratory-prepared or commercial carbon microsphere particles evaluated in this study. These extremely fine particle sizes would readily explain the large amount of atmospheric 
Table 7 MICROSPHEROID ANALYSES

\begin{tabular}{|c|c|}
\hline Carbon (\%) & 92.34 \\
\hline Bulk Density $\left(\mathrm{gm} / \mathrm{cm}^{3}\right)$ & 1.809 \\
\hline Real Density $\left(\mathrm{gm} / \mathrm{cm}^{3}\right)$ & 1.976 \\
\hline Surface Area $\left(\mathrm{m}^{2} / \mathrm{gm}\right)$ & 3.202 \\
\hline Porosity (\%) & 8.42 \\
\hline Porosity Less Than 10 Micrometers (\%) & 98.31 \\
\hline $\begin{array}{l}\text { Volume-Averago Equivalent Poro } \\
\text { Dlameter ( } \mu(n) \text { ) }\end{array}$ & 1.33 \\
\hline
\end{tabular}

SUMMARY.OF FLUIDIZED PETROLEUM COKE

dusting observed from the use of these powders in actual metal fire-fighting tests. Although the commercial sodium chloride powder has a larger average particle diameter, considerable atmospheric dusting has also been observed with this powder in metal fire-fighting tests. Microscopic examination of this material has shown that some extremely fine sodium chloride powder is associated with the larger sodium chloride crystals, as emphasized in Figure 14.

\section{DISCUSSION}

Water should never be applied in small quantities to burning metals or fires of pyrophoric materials since a violent explosion could result (from secondary hydrogen formed) or the fire may be spread by this action. Ordinary sand, even when dry, is also a very poor material for extinguishing metal fires in that it may react with the hot metal and add more heat to an already intense fire. (3) Fire tests conducted with lithium metal and dry sand as an extinguishant showed that when a shovel full of the dry sand was applied to the fire, a persistent, vigorous flaring of the fire resulted. (4) Zirconium silicate powder and calcium carbonate powder likewise produced flaring and sputtering when applied to a lithium metal fire.

Table 8

GPIICRICITY OR FLUIDIZED FETROLEUM COKE MICROSPHEROIDS

\begin{tabular}{|c|c|c|}
\hline \multicolumn{2}{|c|}{$\begin{array}{c}\text { Paíticle Diäinittei al 15X } \\
\text { (mm) }\end{array}$} & \multirow{2}{*}{$\begin{array}{l}\text { Ratio } \\
\text { Major Axis to } \\
\text { Minor Axis }\end{array}$} \\
\hline $\begin{array}{l}\text { Major } \\
\text { Axis } \\
\end{array}$ & $\begin{array}{l}\text { Minor } \\
\text { Axis }\end{array}$ & \\
\hline 20 & 14 & 1.42 \\
\hline 11 & 9 & 1.22 \\
\hline $\mathbf{5}$ & 4 & 1.25 \\
\hline 8 & 6 & 1.3 .3 \\
\hline 9 & 6 & 1.50 \\
\hline 9 & 8 & 1.12 \\
\hline 10 & 10 & 1.00 \\
\hline 13 & $10^{\circ}$ & 1.30 \\
\hline 10 & 7 & 1.42 \\
\hline 7 & 5 & 1.40 \\
\hline 10 & 8 & 1.25 \\
\hline 8 & 5 & 1.60 \\
\hline 9 & 8 & 1.12 \\
\hline 6 & 5 & 1.20 \\
\hline 6 & 6 & 1.00 \\
\hline 8 & 8 & חח 1. \\
\hline 13 & 10 & 1.30 \\
\hline 6 & 5 & 1.20 \\
\hline 5 & 4 & 1.25 \\
\hline \multirow[t]{2}{*}{7} & 6 & 1.16 \\
\hline & & 1.25 \\
\hline
\end{tabular}


Table 9

PARTICLE-SIZE DISTRIBUTIONS OF VARIOUS EXTINGUISHING AGENTS FOR METAL FIRES

\begin{tabular}{lccc}
\hline & & \multicolumn{2}{c}{ Percent Less Than the Given Diameter $(\mu \mathrm{m})$} \\
\cline { 3 - 4 } Particle. & 90 & 50 & 10 \\
\hline Coked Cation-Resin Microspheres & 507 & 290 & 162 \\
$\begin{array}{l}\text { Fluidized Petroleum Coke Microspheroids } \\
\text { Commercial Carbon Microspheres Derived }\end{array}$ & 288 & 172 & 108 \\
$\begin{array}{l}\text { from Pitch } \\
\text { Commercial Sodium Chloride }\end{array}$ & 200 & 128 & 100 \\
Commercial Ammonium Phosphate & & & 113 \\
Graphite Flour & 320 & 245 & 17.6 \\
\hline
\end{tabular}

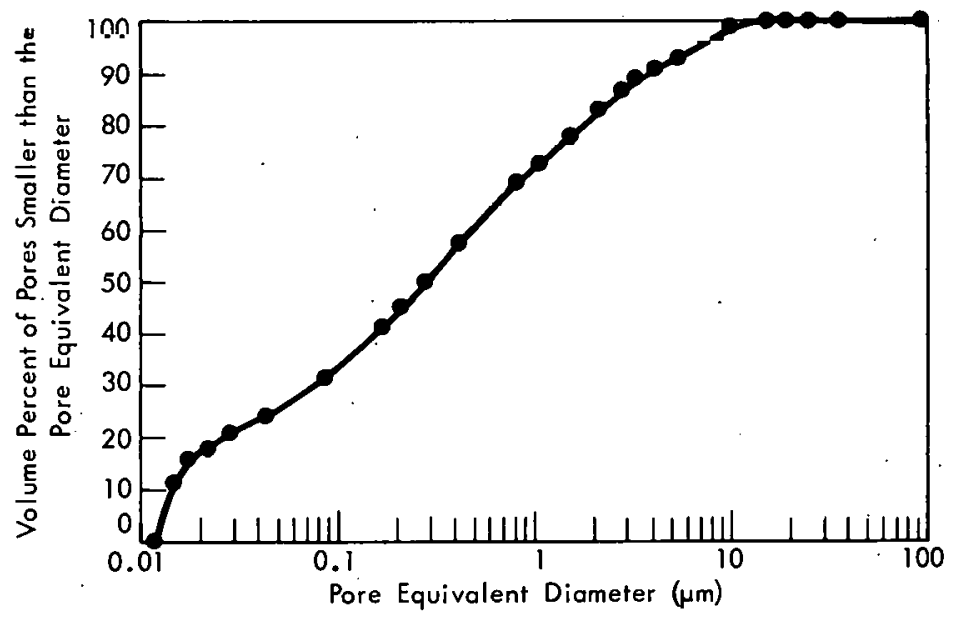

Figure 9. PORE-SIZE DISTRIBUTION OF FLUIDIZED PETROLEUM COKE MICROSPHEROIDS.

In these fire tests with sodium, potassium, and lithium metal, graphite powder was recommended as an effective extinguishing agent for all metal fires, and a specially treated sodium chloride powder was also found to be very effective on sodium metal fires. A serious disadvantage of using sodium or potassium chloride powders as metal fire extinguishants is the extreme corrosivity of chlorides. If, for example, sodium chloride was used to fight a metal fire involved in machine shop operations where pyrophoric chips and turnings were generated from such metals as magnesium, uranium, thorium, and plutonium, severe corrosion of costly machining lathes and fixtures would rapidly ensue.

A patent application has been filed on the use of carbon microspheres as an extinguishant for metal fires. While this invention has been described in terms of carbon or graphite 


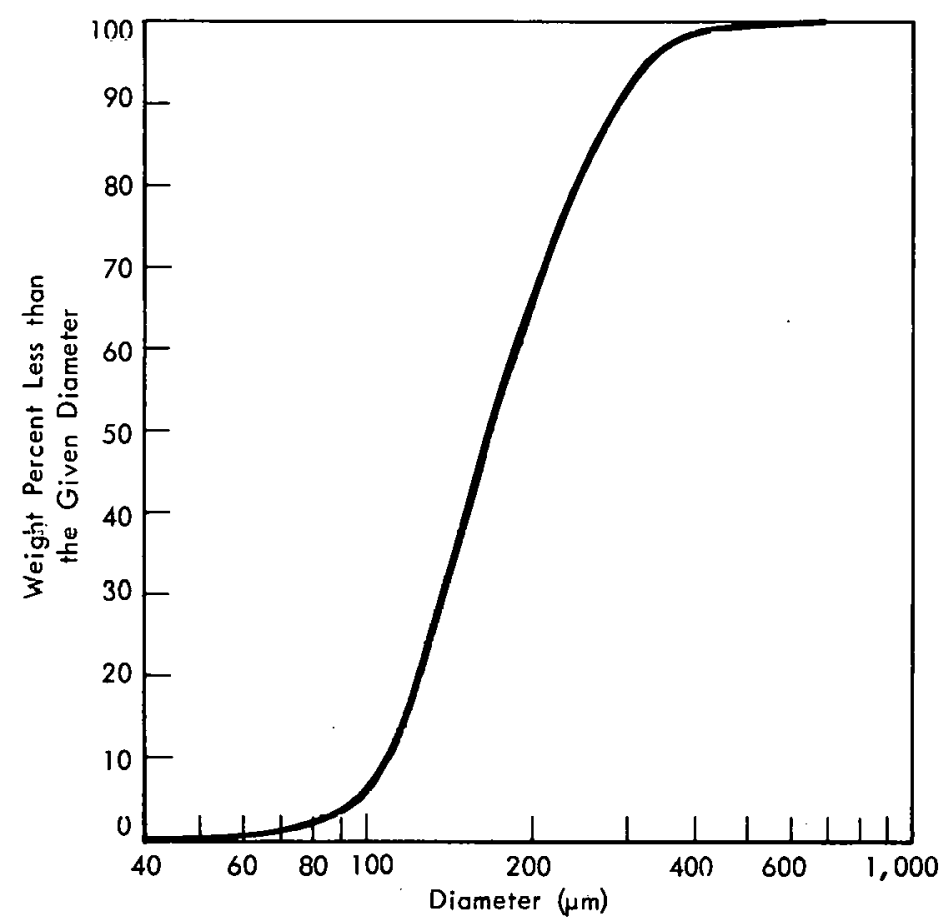

Figure 10. PARTICLE-SIZE DISTRIBUTION OF FLUIDIZED PETROLE UM COKE MICROSPHEROIDS.

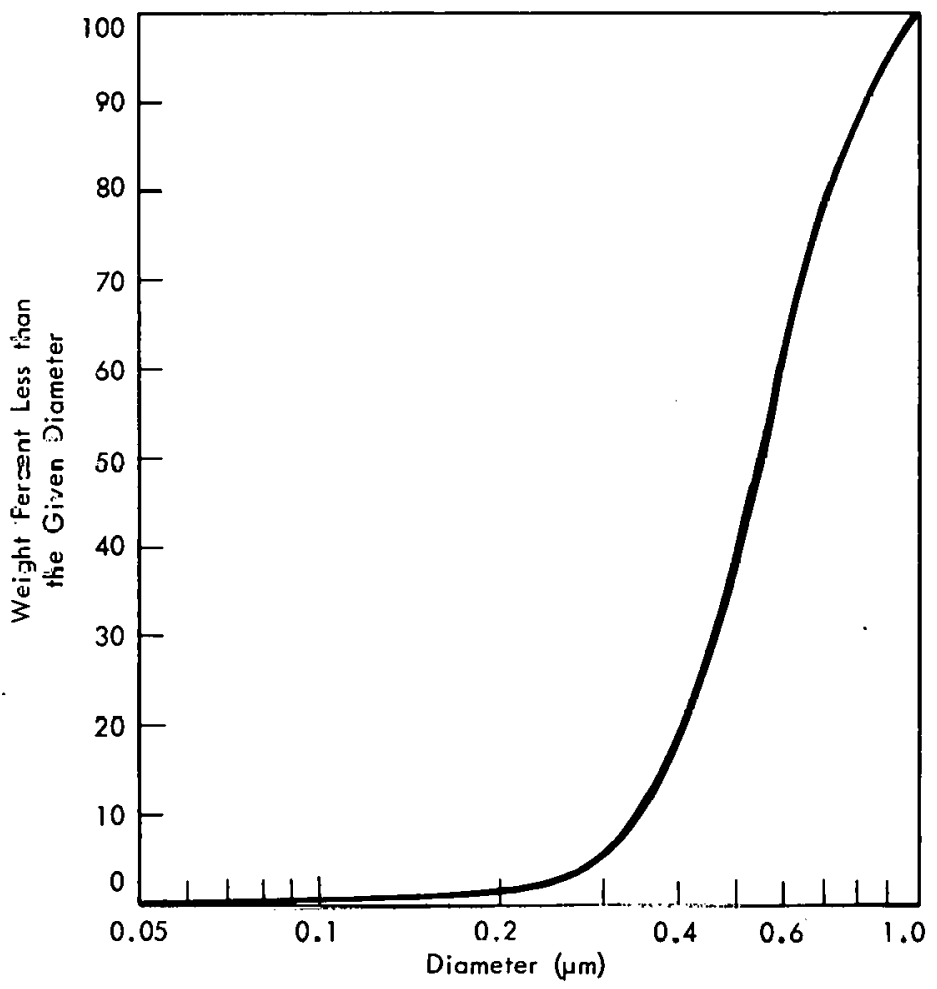

Figure 11. PARTICLE-SIZE DISTRIBUTION OF GRAPHITE FLOUR. 


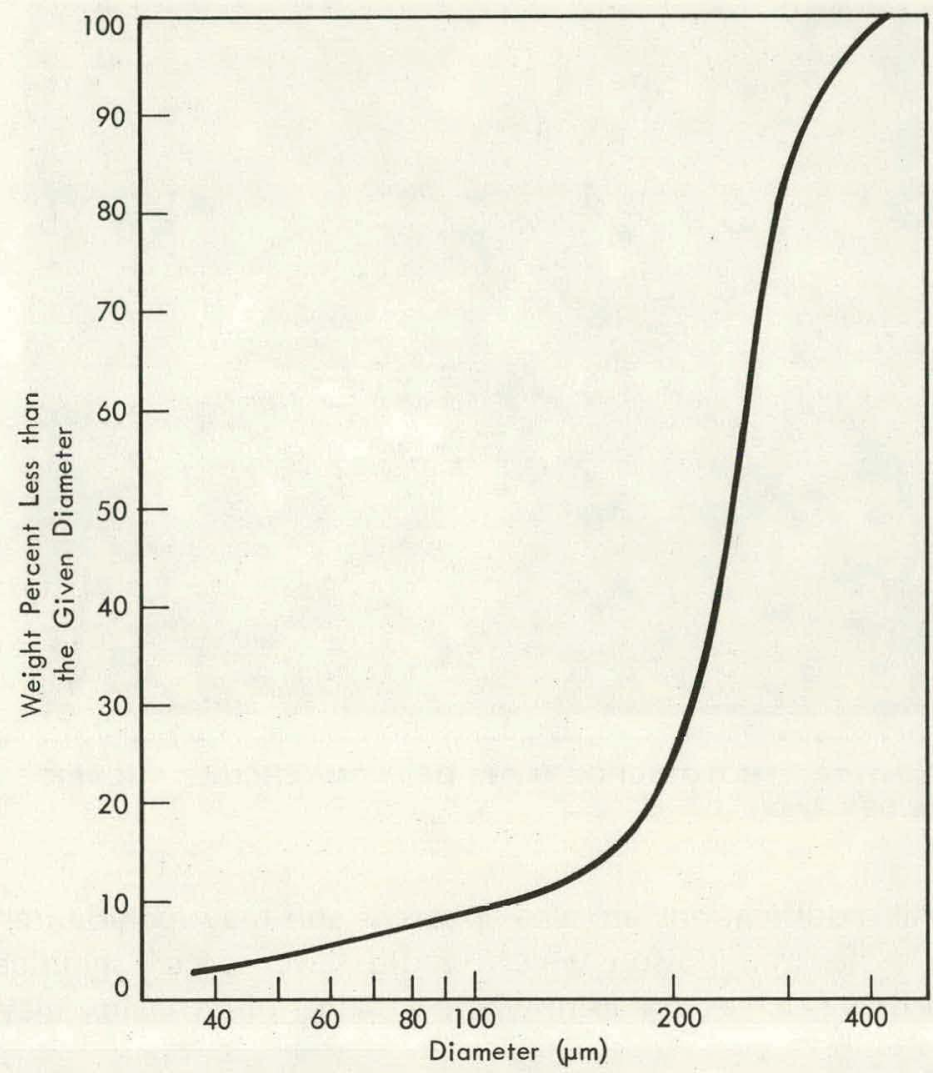

Figure 12. PARTICLE-SIZE DISTRIBUTION OF COMMERCIAL CHLORIDE POWDER.

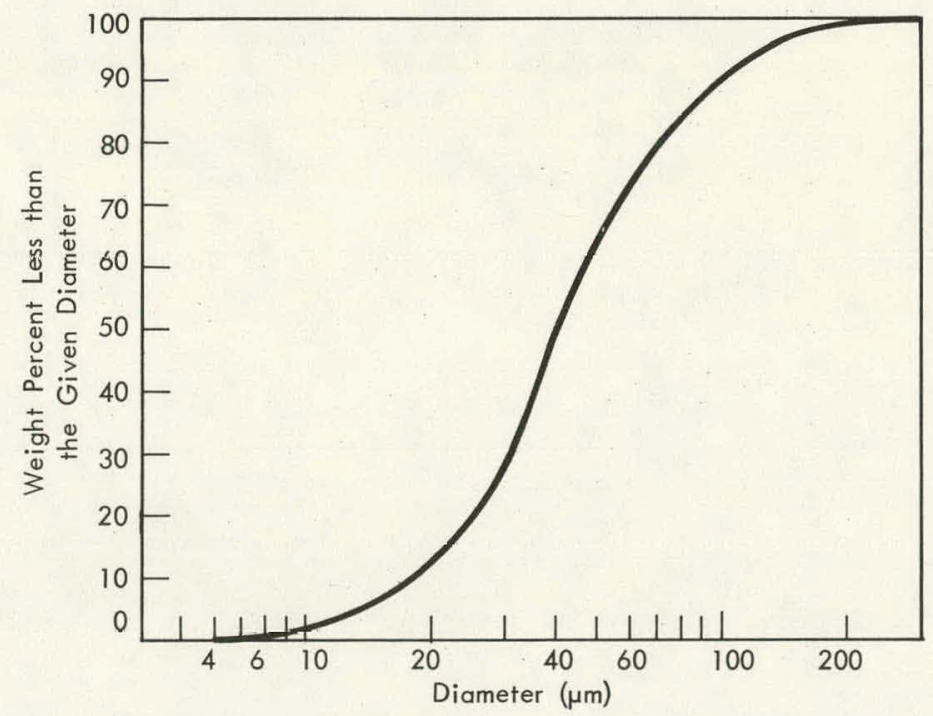

Figure 13. PARTICLE-SIZE DISTRIBUTION OF COMMERCIAL PHOSPHATE POWDER. 


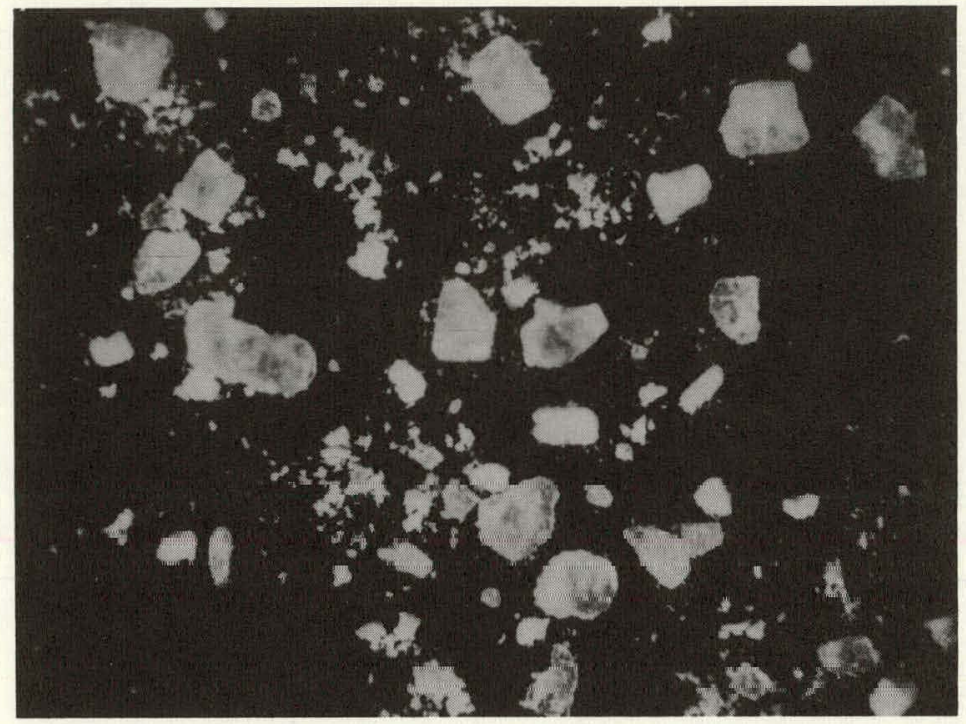

Figure 14. PHOTOMICROGRAPH OF COMMERCIAL CHLORIDE POWDER, (20X)

microspheres, several modifications are also apparent and may include impregnation of the microspheres with a neutron poison which would have special significance for use on fissionable material fires (such as uranium) where a danger of criticality may exist. 


\section{REFERENCES}

(1) Guide for Safety in the Chemical Laboratory, Second Edition, p.199; Manufacturing Chemists Association, Van Nostrand Reinhold Co, New York, New York.

(2) Tryon, G. H.; "Baking Soda is for Baking", Fire Journal, 64 (3) (1970).

(3) Sax, N. L.; Dangerous Properties of Industrial Materials, p 144; Reinhold Publishing Co, New York, New York (1963).

(4) Alkali Metals Reactions and Fire Control, Oak Ridge National Laboratory, Oak Ridge, Tennessee (1953). 


\section{ACKNOWLEDGEMENTS}

The assistance of the following $\mathrm{Y}-12$ people is gratefully acknowledged: J. W. McCormick for the metal fire-fighting tests, C. K. Keyes for particle-size distribution studies and photomicrographs, and E. F. Greer and F. E. Clark for furnishing samples of various dry-chemical extinguishing agents. 


\section{DISTRIBUTION}

Atomic Energy Commission - ORO

Handler, R.

Hickman, H. D.

Lenhard, J. A.

Travis, W. H.

Zachry, D. S., Jr

Oak Ridge Gaseous Diffusion Plant

Patton, F. S.

Richardson, W. L.

Wilcox, W. J., Jr

Winkel, R. A.

\section{Oak Ridge National Laboratory}

Bruce, F. R.

Bender, $M$.

Oak Ridge Y-12 Plant

Alvey, H. E.

Bailey, H. L.

Bernander, N. K.

Briscoe, O. W.

Burditt, R. B.

Burkhart, L. E.

Butturini, W. G.

Choat, E. E.

DeMonbrum, J. R. (5)

Denny, A.

Dodson, W. H.

Ebert, J. M.

Ellingson, R. D.

Evans, G. W.

Foulk, D. L.

Greer, E. F.

Gritzner, V. B.

Hensley, C. E.'

Hill, D. G.

Hoy, H. C.

Johnson, C. E.

Jones, F. W.
Jordon, R. G.

Kahl, K. G.

Keith, Alvin

Kite, H. T.

Lundin, M. I.

Marrow, G. B.

McCormick, J. W.

McLendon, J. D.

Mitchel, G. W.

Oliphant, G. W.

Perry, A. E.

Schmitt, C. R. (15)

Schreyer, J. M.

Smith, J. H:

Smith, R. D.

Snyder, H. G. P.

Stoner, $H$. $H$.

Tench, F: $M$.

Thompson, J. E.

Tewes, W. E.

Tilson, F. V.

Trotter, T. C.

Weathersby, W. E.

Williams, R. D.

Yaggi, W. J./Googin, J. M.

Y-12 Central Files (5)

$Y-12$ Central Files (master copy)

$Y-12$ Central Files (route)

Y-12 Central Files (Y-12RC)

Paducah Gaseuuus Diffuslon Plānt

Levin, R. W.

Millican, $R$.

Merriman, J. R.

Union Carbide-South Charleston

Hilado, C. J.

In addition, this document is distributed in accordance with the category UC-4, Chemistry, as given in the USAEC Standard Distribution Lists for Unclasslfied Scientific and Technical Reports, TID-4500. 